\title{
Tensile Test of Corrugated 8 YSZ Thin Films for SOFC
}

\author{
Kazuo TomidA, Tatsuru NAMIKAWA and Yohtaro YAMAZAKI*
}

Received December 17, 1993 ; Accepted June 7, 1994

\begin{abstract}
Spatial fluctuations in temperature in planar solid oxide fuel cells(SOFCs) cells, and differences in the thermal expansion coefficients between ceramic electrolyte and metal cell component materials affect the performance and durability of planar SOFC stacks. In this study, We developed a method to prepare $8 \mathrm{~mol}_{\%} \mathrm{Y}_{2} \mathrm{O}_{3}-\mathrm{ZrO}_{2}(8 \mathrm{YSZ})$ thin films having corrugated structures to release the thermal stresses. Ni foil substrates were corrugated by folding, and 8YSZ thin films were deposited on the substrates by electron beam evaporation. The substrates were dissolved in $\mathrm{FeCl}_{3}$ aqueous solution, and $8 \mathrm{YSZ}$ thin films with corrugated patterns were obtained. The tensile strength of the films was measured. The difference in strain between $8 Y S Z$ and Ni components at $1000^{\circ} \mathrm{C}$ was calculated from their thermal expansion coefficients. By comparing the experimental data with the calculated value, it is expected that the thermal stresses can be released by corrugating $8 Y$ SZ electrolyte films.
\end{abstract}

\section{INTRODUCTION}

The research and development on planar SOFC have advanced rapidly in recent years because of its high power density and simple cell structure, as compared with tubular SOFCs ${ }^{1-3)}$. However, many problems still remain to be solved. Temperature distribution in a cell, and the difference in thermal expansion coefficients of solid oxide electrolyte and metal materials cause the thermal stresses during the thermal cycles between room temperature and operating temperature. The stresses largely affect the characteristics and durability of planar SOFC stacks ${ }^{4,5}$. Some separator materials having the same thermal expansion coefficient of solid electrolyte have been proposed to solve this problem. In this paper, however, we present solid electrolyte thin films having a unique structure to release the thermal stresses. An example of such film structure is shown in Fig. 1. It is expected that the thermal stresses are relaxed at the waved buffer zone in the electrolyte film because the buffer zone can be elastic for in-plane directions.

In this paper, solid electrolyte thin films having a corrugated structure are fabricated, and their tensile

Department of Electronic Chemistry, Interdisciplinary Graduate School of Science and Engineering, Tokyo Institute of Technology (4259 Nagatsuta, Midoriku, Yokohama 227, Japan)

Key words : Thermal stresses, Electron Beam Evaporation, Corrugated YSZ Film, Tensile Strength strength is measured. Film preparation conditions and the structure of the electrolyte films are also discussed.

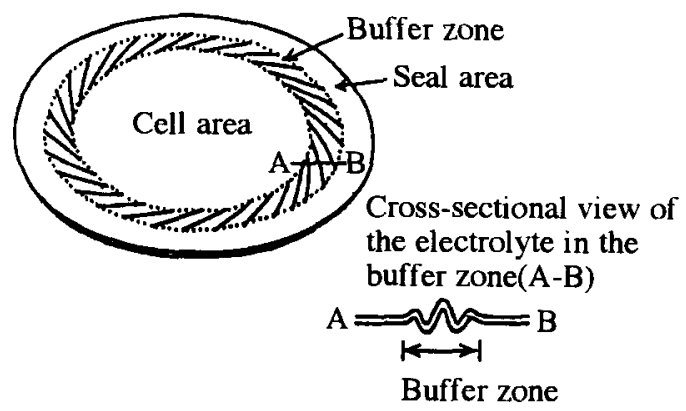

Fig. 1 Schematic drawing of an electrolyte sheet with a buffer zone which can release the stresses between cell area and seal area.

\section{EXPERIMENTAL}

The preparation process of corrugated $8 \mathrm{YSZ}$ thin films is as follows. Thin $10 \mu \mathrm{m}$ thick nickel foil is used as substrate. The nickel foil was corrugated by folding. The substrates were placed about $10 \mathrm{~cm}$ above the evaporation source and were heated in air at $700^{\circ} \mathrm{C}$ for $1 \mathrm{~h}$ to form nickel oxide layer on the surface. Then 8YSZ thin films were deposited by vacuum evaporation using an electron beam heating device ${ }^{6,7}$. The evaporation source was prepared by sintering pellets consisting of $8 \mathrm{~mol} \% \mathrm{Y}_{2} \mathrm{O}_{3}-\mathrm{ZrO}_{2}$ powder (TOSOH TZ-8Y) at $1100^{\circ} \mathrm{C}$ for 5 h. $8 Y$ SZ films 
were deposited in a vacuum of $6 \times 10^{-3} \mathrm{~Pa}$ at a substrate temperature of $700^{\circ} \mathrm{C}$. After the deposition of electrolyte films, the substrates were kept at $700^{\circ} \mathrm{C}$ and air was gradually introduced in the chamber so as to keep the substrate temperature constant. Through this process, the as-deposited electrolyte films were annealed and the anion defects remaining in the films were eliminated. The nickel foil substrates were dissolved in $0.25 \mathrm{M} \mathrm{FeCl}_{3}$ aqueous solution for $30 \mathrm{~h}$ at room temperature and corrugated $8 Y S Z$ thin films were obtained. Some of the corrugated films were thickened by additionally depositing 8YSZ layers at $700^{\circ} \mathrm{C}$ in order to analyze effect of the thickness. Some of the prepared films were annealed at $1100^{\circ} \mathrm{C}$ for $3 \mathrm{~h}$. The tensile strength of the prepared electrolyte films was measured. Fig. 2 shows the experimental apparatus for tensile stress measurement. This tensile tester consists of a sample holder and a micrometer to measure the strain. The tensile tester is designed to protect sample films from mechanical shocks when the load is applied. The tensile tester was mounted on a stand with an optical microscope to detect cracks.

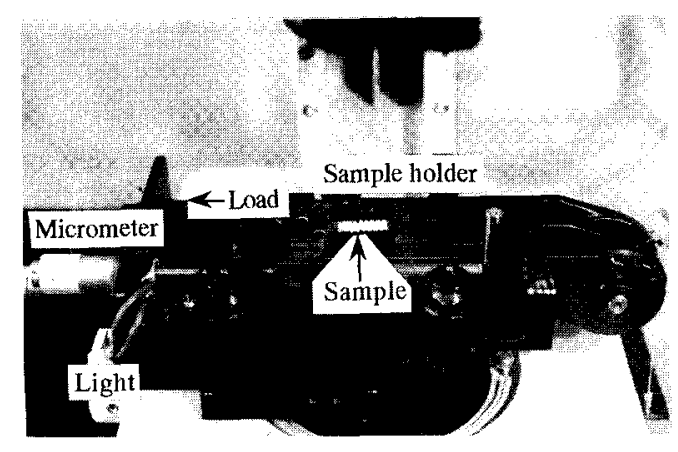

Fig. 2 Experimental apparatus for the tensile test of corrugated $8 Y$ SZ thin films.

\section{RESULTS AND DISCUSSION}

\subsection{Film quality and structure}

A corrugated nickel foil substrate is shown in Fig. 3(A). A fabrication machine with precision gears was assembled so as to produce equally spaced corrugated nickel foil during the experiment. A corrugated 8 YSZ thin film obtained by dissolving a nickel foil substrate is shown in Fig. 3(B). The 8YSZ thin film having the same form of the nickel substrate was obtained. No cracks were observed in the 8YSZ thin film and the surface was glossy. It was concluded
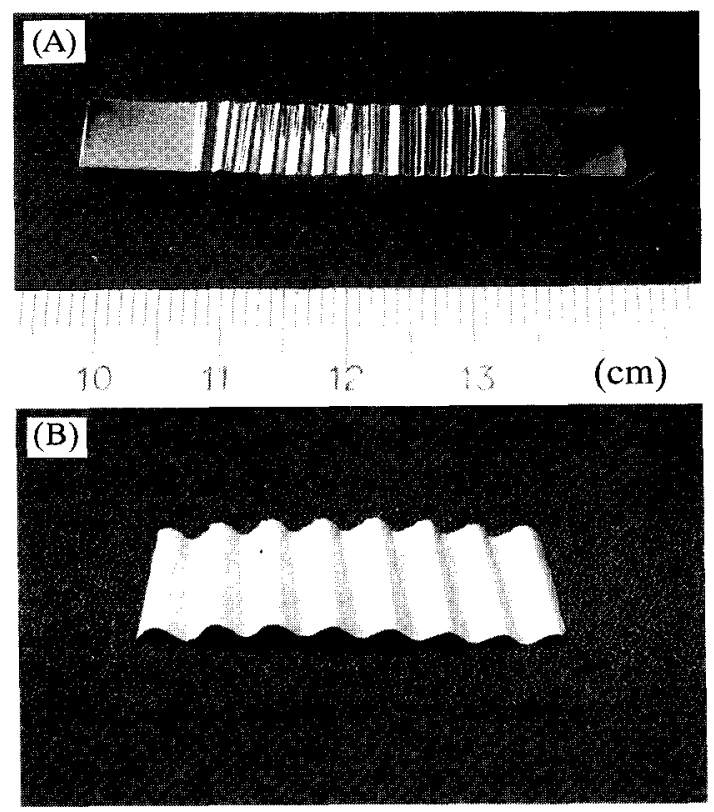

Fig. 3 Corrugated $\mathrm{Ni}$ foil substrate(A) and the corrugated YSZ thin film obtained by dissolving the $\mathrm{Ni}$ foil substrate(B)

that $8 \mathrm{YSZ}$ thin films were not damaged by the $\mathrm{FeCl}_{3}$ aqueous solution $(0.25 \mathrm{M})$.

The $\mathrm{X}$-ray $(\mathrm{CuK} \alpha)$ diffraction patterns of asdeposited YSZ film prepared with the substrate temperature of $700^{\circ} \mathrm{C}$, and that of the film annealed at $1100^{\circ} \mathrm{C}$ for $3 \mathrm{~h}$ are shown in Fig. 4. This result showed that the most part of both films was cubic phase and was not tetragonal. These data lead to the result that cubic 8YSZ films are formed with the evaporation source of $8 \mathrm{~mol} \%$ yttria stabilized zirconia.

\subsection{Tensile test of corrugated 8 YSZ film}

The tensile strength of the as-deposited corrugated

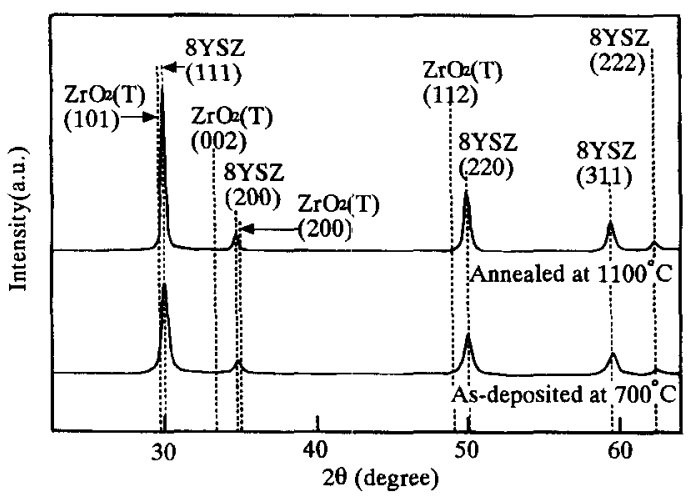

Fig. $4 \mathrm{X}$-ray diffraction patterns of $8 \mathrm{YSZ}$ film. 
$8 Y S Z$ thin films with thickness from 40 to $80 \mu \mathrm{m}$ was measured. The sample width was $6 \mathrm{~mm}$, its length was $10 \mathrm{~mm}(6$ pitches $/ 10 \mathrm{~mm})$. Figure 5 shows the result where $\Delta \mathrm{L}$ is expansion and $\mathrm{L}_{0}$ is initial length of the sample. The thermal strains of both nickel and $8 \mathrm{YSZ}$ at $1000^{\circ} \mathrm{C}$ are calculated from their thermal expansion coefficients. From the calculation, the strain caused by the thermal expansion difference between $\mathrm{Ni}$ and $8 Y S Z$ is $0.82 \times 10^{-2}$. This value is indicated in the figure. All the samples can relax thermal stresses which are caused by the difference in thermal expansion coefficients between $8 Y S Z$ and Ni. All values of $\Delta \mathrm{L} / \mathrm{L}_{0}$ for the corrugated 8YSZ films at fracture was about $2.4 \times 10^{-2}$. This result shows $\Delta \mathrm{LL}_{0}$ at fracture for as-deposited films is not very influenced by the variation of thickness.

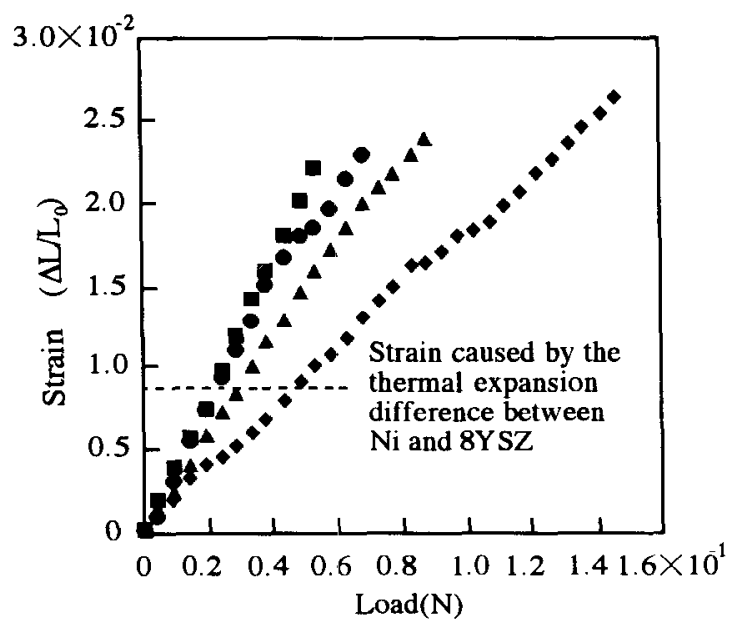

Fig. 5 Tensile test of as-deposited corrugated 8YSZ thin films, $40 \mu \mathrm{m}$ thick, $43 \mu \mathrm{m}, \Delta: 60 \mu \mathrm{m}$, $80 \mu \mathrm{m}$.

Figure 6 shows the tensile strength of as-deposited and annealed at $1100^{\circ} \mathrm{C}$ films of thickness $40 \mu \mathrm{m}$. A crack was induced in as-deposited film when the tension was $5.39 \times 10^{-2} \mathrm{~N}$, and in the annealed film, a crack was observed when the tension was $18.6 \times$ $10^{-2} \mathrm{~N}$. This result shows that Young's modulus increased when the as-deprosited films were annealed at $1100^{\circ} \mathrm{C}$.

The tensile strength was also measured for the thickened and annealed films. The result is shown in Fig. 7. This result shows that $\Delta \mathrm{L}_{0}$ of the annealed films at fracture is affected by the additional deposi

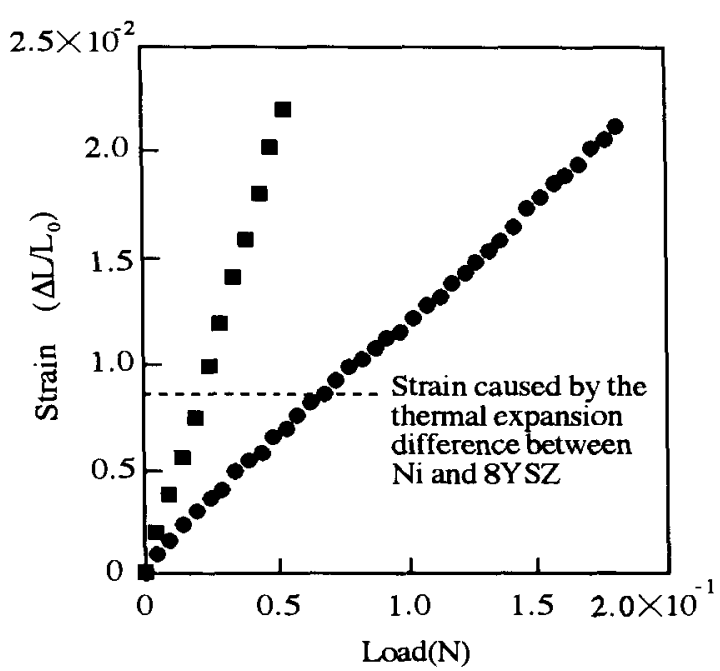

Fig. 6 Tensile test of $40 \mu \mathrm{m}$ thick corrugated 8YSZ thin films, $\mathbf{D}$ : as-deposited, 0 : annealed at $1100^{\circ} \mathrm{C}$.

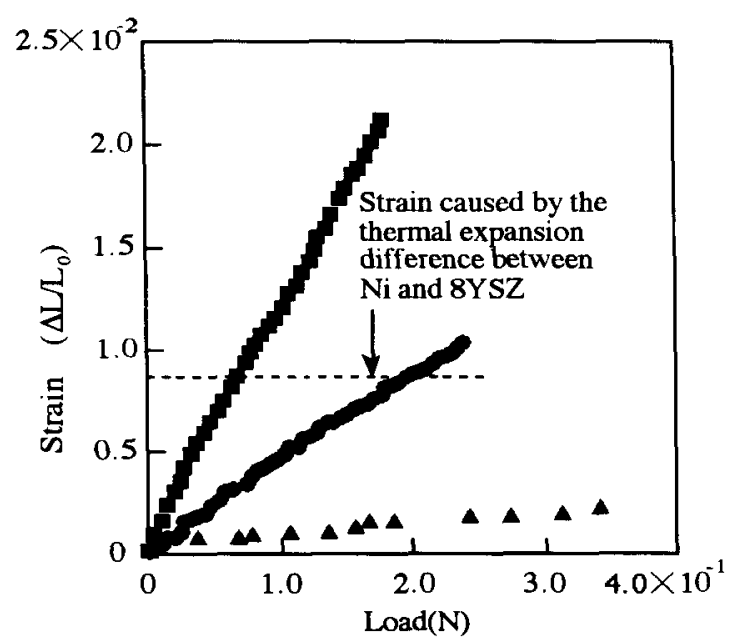

Fig. 7 Tensile test of corrugated 8YSZ thin films annealed at $1100^{\circ} \mathrm{C}, \mathrm{C}: 40 \mu \mathrm{m}$ thick, $60 \mu \mathrm{m}, \Delta$ : $80 \mu \mathrm{m}$.

tion of 8YSZ. The annealed $80 \mu \mathrm{m}$ thick film can not relax the strain caused by the thermal expansion difference.

Table 1 shows the slope of the stress-strain curves for the corrugated $8 Y$ SZ films with various thicknesses. The values were obtained by the least square method. The slope of annealed and $40 \mu \mathrm{m}$ thick film is about $1 / 4$ of as-deposited film. The slopes of the 60 and $80 \mathrm{~mm}$ thick annealed films are smaller than 
Table 1 Slope $\left(10^{-3} \mathrm{~g}^{-1}\right)$ for the stress-strain curves.

\begin{tabular}{l|cccc}
\hline \multirow{2}{*}{$\begin{array}{l}\text { Annealing } \\
\text { temperature }\end{array}$} & $40 \mu \mathrm{m}$ & $43 \mu \mathrm{m}$ & $60 \mu \mathrm{m}$ & $80 \mu \mathrm{m}$ \\
\hline $\begin{array}{l}\text { as-deposited } \\
\text { at700 } \\
1100^{\circ} \mathrm{C}\end{array}$ & 4.05 & 3.33 & 2.33 & 1.73 \\
\multicolumn{1}{c}{110} & - & 0.419 & 0.0546 \\
\hline
\end{tabular}

Table 2 Expansion ratio( $\left.\Delta \mathrm{L} / \mathrm{L} / \mathrm{N}, 10^{-2}\right)$ for corrugated $8 Y S Z$ films at fracture.

\begin{tabular}{c|cccc}
\hline $\begin{array}{c}\text { Annealing } \\
\text { temperature }\end{array}$ & $40 \mu \mathrm{m}$ & $43 \mu \mathrm{m}$ & $60 \mu \mathrm{m}$ & $80 \mu \mathrm{m}$ \\
\hline as-deposited & 2.20 & 2.28 & 2.38 & 2.61 \\
$1100^{\circ} \mathrm{C}$ & 2.11 & - & 1.03 & 0.211 \\
\hline
\end{tabular}

as-deposited films. Table 2 shows the values of $\Delta \mathrm{L} / \mathrm{L}_{0}$ at fracture for the corrugated $8 Y$ SZ films.

\subsection{Observation of corrugated YSZ films}

Figure 8 shows a cross-sectional microphotograph of a $8 Y$ SZ thin film on a corrugated nickel substrate. Before the experiment, it had been considered that the thickness of the deposited 8YSZ thin film would not be constant, that is, the thickness of the film would be thin at a top or slope and be thick at a bottom of the wave of the corrugated nickel foil substrate. However, from Fig. 8, the thickness of the film was almost constant on a whole corrugated nickel substrate.

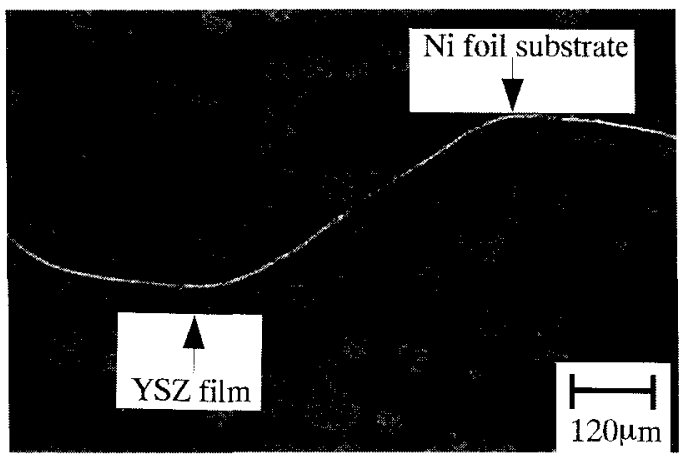

Fig. 8 Cross sectional view of a YSZ thin film deposited on the corrugated nickel foil substrate.

Figure 9 (a) shows a SEM image of the surface of an as-deposited corrugated YSZ film. A SEM image of the surface of a film annealed at $1100^{\circ} \mathrm{C}$ is shown in Fig. 9 (b).These micrographs show that the surface of the film becomes smooth when it is annealed at $1100^{\circ} \mathrm{C}$. The crystal sizes of the film before and after the annealing were estimated from $\mathrm{X}$-ray diffraction data using the Scherrer's. equation(8). From the calculation, the crystal sizes before and after the annealing were $61.8 \mathrm{~nm}$ and $210.0 \mathrm{~nm}$, respectively.
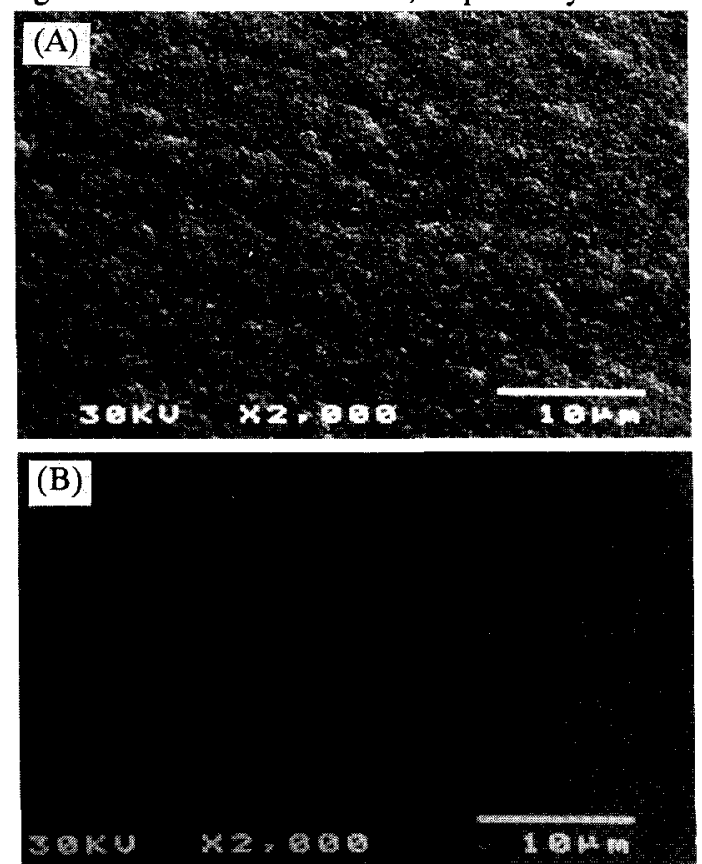

Fig. 9 SEM images on surface of corrugated 8YSZ thin films, (A) as-deposited, (B) annealed at $1100^{\circ} \mathrm{C}$.

\subsection{Cycle test for the expansion of corrugated 8YSZ films}

Figures 10 and 11 show result of the cycle tests of the expansion of $40 \mu \mathrm{m}$ thick corrugated 8YSZ thin films. In this test, corrugated $8 Y$ SZ thin films was expanded until $\Delta \mathrm{LL}_{0}=0.82 \times 10^{-2}$ (strain caused by the thermal expansion difference between $\mathrm{Ni}$ and $8 \mathrm{YSZ}$ at $1000^{\circ} \mathrm{C}$ ), and then load was decreased to $\mathrm{ON}$. Figure 10 shows the result of an as-deposited film. The load was cycled 3 times between $2.45 \times$ $10^{-2} \mathrm{~N}$ and $0 \mathrm{~N}$. Figure 10 shows that as-deposited film repeats reproducible stretching. Figure 11 shows the cycle test for an annealed film. A load of $7.35 X$ $10^{-2} \mathrm{~N}$ was applied. Both films was not fractured during the cycle tests. It is thought that corrugated 8YSZ films are durable to thermal stresses during the thermal cycles between room temperature and operating temperature. 


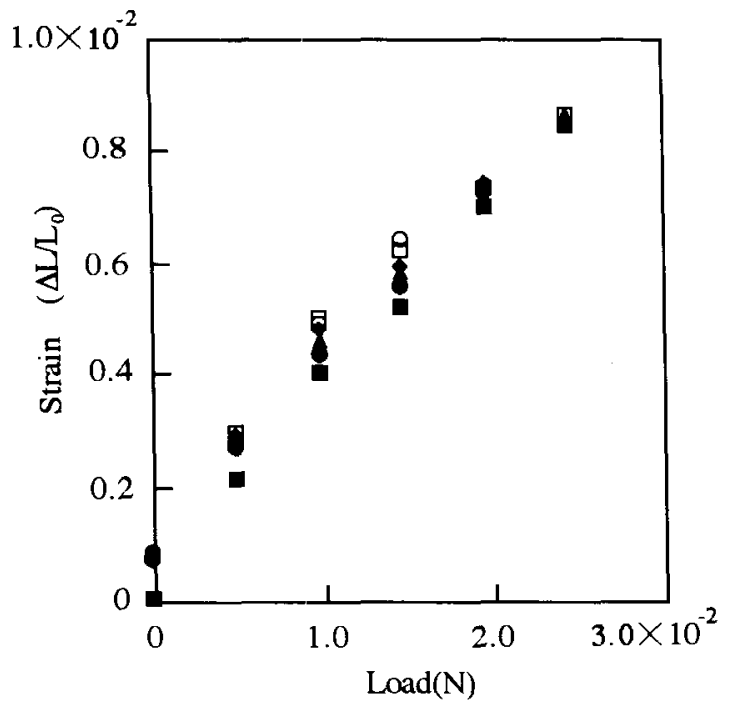

Fig. 10 Cycle test of the expansion of $40 \mu \mathrm{m}$ thick, as-deposited corrugated 8YSZ film, n: first expansion, 0 : return to zero, $\Delta$ : 2nd expansion, $\$$ : 2nd release, $\square: 3$ rd expansion, $0: 3$ rd releas

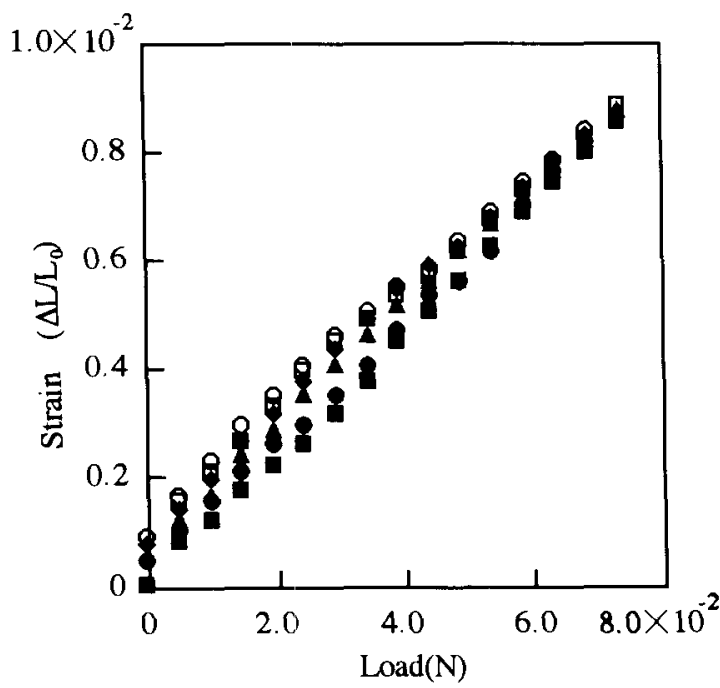

Fig. 11 Cycle test of the expansion of $40 \mu \mathrm{m}$ thick, $1100^{\circ} \mathrm{C}$ annealed corrugated 8YSZ film, $\mathbf{0}$ : first expansion, $\bullet$ : return to zero, $\Delta$ : 2nd expansion, $\bullet$ : 2nd release, $\square$ : 3 rd expansion, $O .3$ rd release.

\section{CONCLUSIONS}

Through the investigation of corrugated $8 \mathrm{YSZ}$ thin films prepared by electron beam evaporation, the following results were obtained. The most part of the film deposited at $700^{\circ} \mathrm{C}$ by evaporating $8 \mathrm{~mol} \%$ yttria stabilized zirconia was cubic phase. Tetragonal phase of $\mathrm{ZrO} 2$ was not detected when the film was annealed at $1100^{\circ} \mathrm{C}$. The film surface became smooth when the as-deposited film was annealed at $1100^{\circ} \mathrm{C}$, at the same time the crystal size increased. It is expected that the corrugated $8 \mathrm{YSZ}$ films are effective to relax the thermal stresses in planar SOFC stacks. The asdeposited corrugated $8 Y$ SZ films relax the strain caused by the thermal expansion difference between $\mathrm{Ni}$ and $8 Y S Z$ at $1000^{\circ} \mathrm{C}$.

This work was supported by the Grant-in-Aid on Priority-Area Research of Energy Conversion and Utilization with High Efficiency, MESC Japan.

\section{REFERENCES}

1) A.O. Isenberg, "Proceedings of the Symposium on Electrode Materials and Processes for Energy Conversion and Storage", The Electrochemical Society, Inc., Vol.77-6, p.512(1977).

2) U.B. Pal and S.C. Singhal," Proceedings of the First Intemational Symposium on Solid Oxide Fuel Cells", The Electrochemical Society, Inc, Vol.8911, p.41, Hollywood, Florida (1989).

3) H. Michibata, T. Namikawa and Y. Yamazaki," Proceedings of the First International Symposium on Solid Oxide Fuel Cells", The Electrochemical Society, Inc., Vol.89-11, Hollywood, Florida (1989).

4) Y. Yamazaki, T. Namikawa, and H. Michibata,"Proceedings of the Second International Symposium on Solid Oxide Fuel Cells", Commission of the European Communities, p.175, Athens, Greece (1991).

5) K. Tomida, T. Namikawa and Y. Yamazaki," Proceedings of the Third International Symposium on Solid Oxide Fuel Cells", The Electrochemical Society, Inc, Vol.93-4,p.74,Hawaii (1993).

6) K. Tomida, T. Namikawa and Y. Yamazaki, Denki Kagaku, 61, 251(1993).

7) H. Michibata, T. Namikawa and Y. Yamazaki, Denki Kagaku, 58, 1070(1990).

8) B.D.Cullity, Elements of X-ray diffraction, AGNE Co-ltd,101(1972) 